\title{
Operações enunciativas e discursivas em um culto televisivo da Igreja Universal do Reino de Deus ${ }^{1}$
}

\author{
Bruno Sampaio Garrido²
}

\begin{abstract}
Resumo: Este trabalho analisou uma pregação do bispo da Igreja Universal do Reino de Deus (IURD) Edir Macedo, exibida no programa Santo Culto em seu Lar. O objetivo foi o de verificar as estratégias discursivas e enunciativas utilizadas na construção do seu discurso e as relações de sentido decorrentes. Pelas análises, constatouse que a pregação do bispo recorre a um jogo enunciativo em que sua autoridade como sacerdote é reforçada, legitimando suas ações e conduzindo constantemente a relação com os interlocutores.
\end{abstract}

Palavras-chave: Igreja Universal do Reino de Deus, tele-evangelismo, midiatização, enunciação, discurso.

Abstract: This study analyzes Bishop Edir Macedo's preaching, from Universal Church of God's Kingdom (IURD), exhibited on the television program Santo Culto em seu Lar. The objective was to verify the discursive strategies used in the construction and enunciation of his discourse and relations of meaning from it. It was found that Bishop's preaching uses a set of enunciation in which his authority as a priest is reinforced, legitimizing his actions and constantly leading the relationship with stakeholders.

Keywords: Universal Church of the Kingdom of God (Igreja Universal do Reino de Deus), tele-evangelism, midiatization, enunciation, discourse. 
A Igreja Universal do Reino de Deus (IURD), fundada em 1977 por Edir Macedo Bezerra, tornou-se a principal corrente religiosa brasileira do neopentecostalismo. Ao pregar um discurso concernente ao que se chama de "teologia da prosperidade", em que o fiel crê que receberá as graças de Deus ainda na vida mortal ao tomar atitudes concretas, a igreja conquistou um número significativo de adeptos ao longo de sua história, oriundos especialmente das classes mais baixas.

A IURD notabiliza-se também pelo farto uso dos meios de comunicação de massa para propagar sua mensagem religiosa, possuindo desde programas radiofônicos matutinos até um jornal com periodicidade regular, dois canais de televisão, além de vários programas televisivos produzidos pela instituição e exibidos na programação aberta.

O objetivo deste trabalho é identificar, a partir da análise de um dos programas veiculados na televisão, os principais elementos constitutivos do discurso religioso adotado pelo bispo Macedo em sua pregação e quais as relações de sentido geradas a partir dos recursos linguísticos utilizados, tomando como base o conceito de fé expresso nas publicações doutrinárias da IURD e na literatura referente aos modos de produção do discurso religioso na televisão.

\section{Religiosidade midiatizada - cenário dos cultos televisivos}

A obra de Assmann (1986) representa um marco teórico dos estudos sobre "igreja eletrônica" no Brasil, por mostrar a ampla utilização dos meios de comunicação pelas igrejas neopentecostais como meio de propagação de suas mensagens. Para o autor, o conceito de "igreja eletrônica" refere-se ao uso dos meios eletrônicos por parte de lideranças religiosas fortemente personalizadas e relativamente autônomas de outras instituições protestantes. São sacerdotes que se tornam "astros" da TV, devido ao seu discurso salvacionista centrado na ascese individual. 
Esse conceito está fortemente vinculado à espetacularização da linguagem televisiva, devido ao suposto emprego de técnicas publicitárias pelos teleevangelistas, cujos programas religiosos também seriam estruturados sob o seguinte esquema, semelhante às mensagens de cunho publicitário:

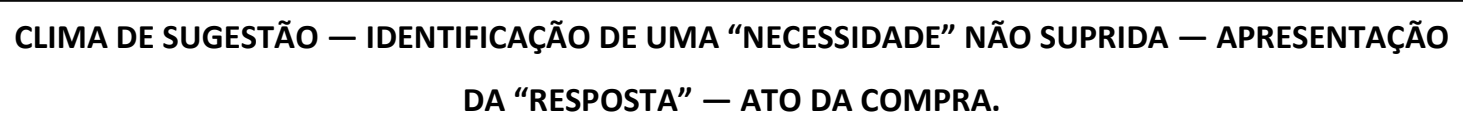

\section{Quadro 1: Esquema das mensagens tele-evangélicas} Fonte: ASSMANN, 1986

As constatações de Sodré (2001) coadunam-se a esse pensamento, tendo em vista que os valores que assentam a religiosidade tradicional têm sido substituídos por outras lógicas, mais imediatistas, individualistas e consumistas. $\mathrm{Na}$ verdade, o autor vai ainda mais longe ao afirmar que teologia e marketing andam lado a lado há tempos:

O fenômeno "mítico-religioso" não é suscitado pelo suposto poder dos conteúdos informativos, mas de um lado (a) por uma lógica mercantil, profético-moralista e autoescatológica, que troca o antigo Bem ético pelo bem-estar individualista, associando salvação e consumo. "Suntuoso é o caminho para a salvação - consuma e sinta-se bem!", ironiza John Carroll, crítico de cultura (SODRÉ, 2001, p. 2).

Tal característica, entre outras, origina-se da crescente midiatização das instituições sociais, decorrentes do desenvolvimento tecnológico e dos meios de comunicação de massa. Esse fenômeno implica principalmente a "subordinação das ações e agendas institucionais a processos de produção que são tomados como empréstimos à esfera do campo dos media" (FAUSTO NETO, 2002a, p. 1).

No âmbito dos fenômenos religiosos, Fausto Neto (2002b) afirma que a midiatização destes implica não apenas mudanças de configuração e atualização de seus mecanismos articulatórios, mas também novos processos de construção de sentido. Os aspectos transcendentais, abstratos e doutrinários das religiões 
em seus formatos convencionais dão lugar a uma relação de "atendimento de demandas", ditada pela lógica do "aqui" e do "agora".

\footnotetext{
Essas demandas, dirigidas aos vários campos sociais, junto a quem já não encontra respostas nem destino para suas questões, são absorvidas, agora, no âmbito de determinadas "políticas de reconhecimento" telerreligioso, cujo cerne não é a tomada em consideração da natureza mesma dos seus conteúdos, mas a sua subordinação aos interesses instrumentais de uma religião movida pela ética do consumo e da prestação do serviço (FAUSTO NETO, 2002b, p. 27).
}

Nesse cenário midiatizado, as religiões criam formas de estabelecer relações tanto com seus fiéis e públicos de interesse quanto com "adversários", deslocando-se do espaço físico (o templo) para o telemidiático. As antigas ações, outrora pautadas pelos limites e parâmetros dos rituais religiosos e em experiências de grupos, são substituídas por ações mais complexas, que vão além das formas tradicionais de interação através das quais os cristãos estruturam e demonstram sua fé (FAUSTO NETO, 2002b).

No caso da IURD, isso se dá de forma sui generis, pela competência e agressividade com as quais a instituição utiliza os meios de comunicação para seus propósitos - aspectos a serem discorridos mais adiante.

\section{Breve histórico da IURD}

O início da IURD, segundo Antoniazzi (1994), partiu da Igreja de Nova Vida, da qual se originaram também a Igreja Internacional da Graça de Deus e a Igreja Cristo Vive. Inicialmente, a igreja de Macedo chamava-se Igreja da Bênção e funcionava em um prédio localizado no bairro carioca da Abolição, onde outrora existia uma funerária.

Na década de 1980, as atividades da IURD ganharam projeção nacional, devido à sua penetração rápida em diversos nichos sociais, o que a fez ganhar a atenção dos noticiários, em geral de forma crítica. Foi no final dessa década 
que aconteceram dois momentos fundamentais para a IURD: a transferência da sede nacional para São Paulo e a compra da Rede Record, em 1989.

Atualmente, a IURD está presente em todo o território nacional, quase toda a América do Sul, Portugal, Estados Unidos, alguns países da África (especialmente os lusófonos, como Angola), da Europa e Ásia. No âmbito nacional, a maior concentração de templos está nos Estados do Rio de Janeiro, São Paulo e Bahia. Segundo dados mais recentes, a igreja está presente em 172 países, possui aproximadamente quatro mil templos no Brasil, oito milhões de fiéis e quase 10 mil pastores (Portal G1, 11/08/09).

Nesse contexto, a projeção da IURD deu-se por uma conjugação de fatores. Primeiramente, o empenho em oferecer o essencial - serviços religiosos aos interessados, além dos conceitos cristãos de compromisso e comunidade, mas sem fazer exigências severas. Segundo, a organização de sua estrutura em torno da missão religiosa - emissoras de rádio e televisão, gráficas, jornais, entre outros. Terceiro, o controle centralizado de seus missionários, com uma constante renovação de seus quadros, o que minimiza a dependência quanto a organizações leigas e a formação de grupos independentes de poder. Quarto, a atuação significativa de mão-de-obra voluntária, composta por convertidos e familiares (ANTONIAZZI, 1994).

\section{A fé segundo a IURD}

Antes de partirmos para a análise do culto televisivo, convém fazermos uma breve revisão do conceito estabelecido pela IURD sobre a fé, já que esse é um dos assuntos centrais abordados pelo bispo Macedo em sua pregação.

Macedo (2002) conceitua dois tipos de fé. A fé natural, racional e pragmática origina-se das sensações captadas pelos cinco sentidos e, a partir delas, o homem norteia as suas ações. Já a fé sobrenatural é um dom concedido por Deus, mediante a intermediação do Espírito Santo, que permite ao fiel acreditar 
neste sem necessitar de prova material e, além disso, o permite realizar feitos grandiosos ou impossíveis (milagres).

Para o bispo, a fé sobrenatural manifesta-se não apenas pela crença em si, mas por meio de demonstrações concretas, principalmente pela prática dizimista. Quando o fiel o faz, adquire também o direito de "cobrar de Deus" pela realização dos milagres outrora prometidos. Tal gesto seria uma forma de o seguidor exercitar a própria fé até que esta se torne sólida (MACEDO, 2002).

Macedo (2002) trata a fé dos seguidores da "igreja primitiva" (uma referência à Igreja Católica) como passiva. Nessa concepção, seria uma fé introspectiva, voltada apenas para as orações. Além disso, os representantes de tal "igreja" estariam mais preocupados com vaidades e intrigas de poder do que com a fé verdadeira no Cristo Jesus.

Em outro livro, Macedo (1999) estabelece uma diferença cabal entre viver com fé e viver pela fé. No primeiro caso, é simplesmente crer na existência do Senhor e em seu poder, algo que qualquer pessoa pode possuir e demonstrar. Já no segundo caso, é viver na dependência do Senhor Jesus, ou seja, ter certeza de que ele, algum dia, irá cumprir as promessas relatadas pela Bíblia Sagrada.

Essa obra também conceitua o valor do sacrifício na doutrina da Igreja como elemento crucial para a fé legítima. Não existe fé verdadeira sem o sacrifício por parte do fiel, pois este gesto é qualificado como um ato de coragem para assumi-la - não se sacrificar é demonstrar uma fé teórica, insignificante (MACEDO, 1999).

\section{Análise da pregação}

Para a constituição do corpus deste trabalho, foi escolhido um culto gravado em julho de 2007 e exibido no programa Santo Culto em seu Lar, veiculado pela Rede Record nas manhãs de sábado e de domingo. Esse 
programa transmite um fragmento de uma das pregações do bispo Macedo (ou de algum de seus sacerdotes), a qual aborda um tema específico, recorrendo frequentemente ao apoio do texto bíblico.

A análise será feita conforme as diretrizes estabelecidas pela Análise Crítica do Discurso (ACD), de maneira a detectar as relações de sentido enredadas no texto (ditas e não ditas). Fairclough (2001a; 2001b), ao conceber o discurso como prática social, também o descreve como uma forma de ação, a partir do uso da linguagem, a qual está sócio e historicamente situada em uma relação dialética com os outros elementos do contexto social. Assim, o discurso não existe por si só, mas é elemento constitutivo das práticas sociais, da mesma forma que por elas é constituído.

Diante disso, a ACD procura analisar as relações frequentemente opacas de causalidade e determinação entre: a) práticas discursivas, eventos e textos e b) estruturas sociais, culturais, relações e processos mais amplos, de maneira a verificar as relações de luta e poder que originaram essas práticas discursivas, sua constituição ideológica e a maneira como tais discursos atuam na consolidação e/ou manutenção de uma ordem vigente (FAIRCLOUGH, 2001a).

Nessa perspectiva analítica, Fairclough (2001a; 2001b) trata a prática discursiva como mediadora entre o texto e a prática social. Assim, os processos de produção e interpretação influenciam na natureza da prática social, ajudando a moldá-la, enquanto que esses mesmos processos também intervêm na forma textual, os quais nela deixam seus rastros. É por meio dessas pistas, decorrentes da prática discursiva, que o analista irá identificar essas relações entre texto e prática social.

Na pregação selecionada para este trabalho, Macedo trata de como se deve ser fiel a Deus. Segundo o bispo, não basta apenas demonstrar a fé de forma introspectiva e mediante o cumprimento de rituais eclesiásticos. A devoção ao Senhor somente se plenifica a partir do pagamento do dízimo, 
entendido aqui como uma compensação dada pelo homem por conta do pecado original, cometido por Adão e Eva. O não pagamento do dízimo equivale, nessa lógica, ao roubo, acarretando ao devoto consequências negativas uma vida miserável e ausente de Deus.

Quanto às estratégias discursivas utilizadas pelo bispo, a primeira a ser notada é a repetição de frases e estruturas de mesmo campo semântico (você sabe que... enquanto Jacó era chamado de Jacó... ele sofreu muito ele gemeu... porque ele foi enganador, ele foi mentiroso, ele foi tapeador). Esse recurso enfatiza elementos específicos que o preletor deseja destacar e ajuda a "prender" o ouvinte, evitando sua dispersão. Além de ser uma marca da oralidade, com finalidade fática, ela também é persuasiva, por ser exercida aqui de forma intensa.

A segunda estratégia é o jogo de perguntas e respostas como a expressa no excerto "Desde o dia de vossos pais o quê? vos desviastes dos meus estatutos e não os guardastes, Tornai-vos para mim... e eu/eu o quê? me tornarei para vós outros; diz o quê?... o senhor dos exércitos...". Ele exerce a mesma função fática da repetição de termos, mas também cria uma relação de proximidade com o ouvinte, mediante uma atmosfera de aparente interatividade, por meio da qual o bispo dá liberdade ao fiel de manifestar-se, embora isso não aconteça de fato.

Outro elemento frequente na pregação é o uso da linguagem coloquial e de expressões conhecidas, até mesmo jocosas ou grosseiras (Quando se fala em filho de Jacó, Deus está repreendendo, está considerando aqueles/ aquelas pessoas como rebeldes idólatras depravadas enfim... Tudo que não presta?). Tal opção tem por finalidade garantir um maior grau de veiculação da mensagem ao maior número possível de indivíduos característica elementar dos meios de comunicação de massa. Logo, isso denota a preocupação da IURD em fazer sua voz chegar o mais longe possível, adequando sua mensagem aos formatos midiáticos. 
É importante mencionarmos nessa discussão um aspecto inerente ao próprio meio televisivo. É o que Brito (1999) chama de situação televisiva, na qual a televisão, através de seu caráter interpelativo, procura estabelecer um vínculo comunicativo com seus espectadores, simulando a interlocução direta em uma situação presencial de comunicação. Desse modo, a utilização de estratégias recorrentes da comunicação oral serve justamente a esse propósito - estabelecer um elo entre enunciador e enunciatário e circunscrevê-los no ato enunciativo, ainda que apenas o enunciador (bispo) e parte dos enunciatários (a plateia) esteja figurativizada.

No entanto, o caráter unívoco da mensagem coloca o ouvinte na mera condição de receptor, a despeito da aparente participação dele graças ao jogo de pergunta-resposta descrito anteriormente. Esse fato, somado ao apelo emocional de citações que tocam o ouvinte e à grande quantidade de termos com valor imperativo, que exortam o fiel a tomar alguma atitude ("... então você tem o direito de questionar Deus..."; "ela [a pessoa que crê em Deus] tem que provar ela tem que mostrar o fato ela tem que... manter comprometimento com Deus"...), cria um ambiente de difícil escapatória, no qual o devoto é "convidado" a seguir as orientações do bispo:

as pessoas às vezes dizem eu creio em Deus, eu creio em Jesus, eu creio na bíblia, mas ela mantém afastada a prática da palavra de Deus... não adianta nada Você pode ser a pessoa que crê em deus de todo o seu coração, mas se você não pratica a palavra dele a sua crença não vale de nada, aí?

(...) isso é importante para a sua vida/pra sua vida e eu não estou falando/ nós não vamos falar do ponto de vista econômico, não; nós estamos falando da vida por inteiro ${ }_{\star}$ que engloba a sua família que engloba o seu tratamento, que engloba a sua saúde, que engloba o seu/a sua prosperidade, o seu sucesso, que engloba toda a sua vida...

No que tange às expressões exortativas, pode-se dizer que elas trazem em si uma dupla finalidade: a) uma função pedagógica, ao explicar e 
interpretar os excertos da Bíblia aos devotos; b) uma função condutora, ao direcionar a leitura e as ações dos ouvintes, fazendo-os focalizar sua atenção conforme os desígnios do bispo. Para isso, Macedo recorre a expressões fáticas, exortações, direcionamento da atenção do espectador àquilo que é considerado importante, interação com a equipe técnica quando se é preciso intervir na condução do programa, em geral sob forma imperativa (FAUSTO NETO, 2002b). As exortações conclamam o fiel a tomar atitudes o tempo todo, de modo a não seguirem o exemplo dos "filhos de Jacó" e levarem uma vida distante de Deus, sujeita aos males do mundo.

\begin{abstract}
Mas vós direis em quê? EM QUE que havemos de tornar? É a pergunta essa aqui, é a pergunta chave do contexto, isso aqui, essa pergunta aqui é a pergunta chave da revelação de Deus para nós. Em que havemos de tornar quer dizer, vocês dizem... Como? O que que nós temos que nos voltar para ti? Como? Se nós somos, mantemos a nossa tradição religiosa, que é o que acontece... as pessoas às vezes dizem eu creio em Deus, eu creio em Jesus, eu creio na bíblia, mas ela mantém afastada a prática da palavra de Deus... não adianta nada.
\end{abstract}

Outro elemento crucial no discurso de Macedo é a função ambivalente das formas de colocação do "eu" e do "você" na enunciação. Na pregação, quando o bispo utiliza o "eu", não significa que esteja se referindo somente à sua pessoa. Há momentos em que ele "se coloca" no lugar dos fiéis, ora para criticar condutas as quais considera falhas ou inadequadas, ora para mostrar a "forma certa" como o seguidor de Deus deve agir frente a Deus e à vida. Em outras circunstâncias, o "eu" se refere ao próprio Deus. A partir dessa ambivalência, o bispo dirige-se a seu público como se representasse o Senhor, investindo-se de sua autoridade ao ler os textos bíblicos e exortar os fiéis a seguir suas orientações.

então Deus está falando Vocês/Vocês estão longe de mim vocês estão afastados e eu não os destruo porque eu não mudo o quê/o que eu era para com o seu pai eu sou ainda hoje e serei para sempre, quer dizer eu não mudo a maneira de ser a minha conduta, porque Deus não muda, é imutável... e Deus continua... Desde o dia de vossos pais o quê? vos desviastes dos meus estatutos e 
não os guardastes. Tornai-vos para mim... e eu / eu o quê? me tornarei para vós outros... Diz o quê?... o senhor dos exércitos...

No trecho supracitado, ainda que Macedo recorra ao discurso direto, dando voz à palavra divina ("então Deus está falando"), isso não ocorre plenamente por não se tratar de uma citação da Bíblia, mas de uma interpretação do próprio sacerdote mesclada a trechos do livro sagrado. Aqui, em virtude desse enunciador ambivalente, sacerdote e divindade se confundem, se "misturam" em uma fala híbrida em que ambos parecem se manifestar.

Com relação ao uso do "você" os espectadores são interpelados face às suas contingências e eventuais necessidades. Nesse caso, todos eles são unificados na condição de um espectador único (o "você"). Essa estratégia confere não apenas um caráter impessoal à enunciação (por se tratar de um receptor generalizado, que na verdade pode ser qualquer pessoa que estiver assistindo ao programa), mas contribui para que o espectador, mesmo diante de um discurso generalizante, se envolva e se conforte com tais palavras, mediante uma imediata identificação com esse discurso - como se fosse dirigido unicamente a ele (FAUSTO NETO, 2002b).

quando você é dizimista fiel você tem o direito / você tem o direito, o privilégio de chegar e dizer: meu Deus, o que que está acontecendo, onde é que tá o erro... quem está errado, eu ou o senhor, porque eu estou cumprindo a minha parte, estou sendo fiel nos meus dízimos... agora a tua palavra diz que o senhor vai abrir as janelas dos céus e eu/eu tô passando privação... isto é justo?... a tua palavra é verdadeira ou é mentirosa?...

Quanto ao uso comum de expressões categóricas (isso é assim, não adianta nada, é isso), tais expressões, além de seu caráter impactante e demonstrativo de uma autoridade do bispo frente aos devotos, corroboram a estrutura do discurso religioso, ao expressar uma "verdade inquestionável" baseada nos ensinamentos de Deus ou expressa diretamente por ele, via Bíblia Sagrada ou preleção do bispo. São maneiras de dizer que tal interpretação 
coaduna-se exatamente com a vontade divina, sem abrir espaço para discussões ou entendimentos paralelos.

As orações subordinativas aparecem frequentemente nas frases construídas, em geral iniciando o período. Quando o faz, Macedo estabelece uma relação de causa e efeito entre uma conduta adotada e um fenômeno decorrente. Ao iniciar o período com a conjunção quando, dá-se ênfase na conduta a ser criticada ou louvada, de modo a criar uma expectativa com relação à consequência prevista.

A frase "quando deus criou os céus e a terra e fez o homem deus deu ao homem domínio sobre tudo tudo, tudo, tudo", uma oração subordinada adverbial temporal, é expressa em ordem inversa, destacando o ato da criação divina ao dar origem a todas as coisas - e estabelecendo uma relação de causalidade e dependência entre os eventos. Nessa época, segundo a pregação, o homem era um ser forte, respeitado e abençoado - condição que seria perdida após a expulsão de Adão e Eva do Paraíso. Isso leva ao entendimento de que Deus quer que o homem retome essa condição, mas, para isso, há um preço a se pagar além da simples crença no Senhor.

Uma estrutura bastante usada ao final da pregação, não basta... mas, exorta o fiel a adotar uma conduta além daquilo que está convencionado a fazer. Assim, o fiel passa a entender suas demonstrações de fé como ineficazes ou insuficientes, sendo necessário tomar atitudes adicionais. A constância dessa estrutura no discurso de Macedo configura uma espécie de cobrança ao fiel, para que este leve sua fé sempre às últimas consequências se quiser ter alguma mudança em sua vida - do contrário, seria uma fé medíocre.

Outra estrutura que transmite o mesmo sentido é a expressa em "Você pode ser a pessoa que crê em Deus de todo o seu coração, mas se você não pratica a palavra dele, a sua crença não vale de nada, aí?". A relação adversativa existente nesse período, dada pelo uso da conjunção mas, coloca em destaque uma qualidade de um eventual fiel, para depois rechaçá-la, tratando-a 
como insuficiente, incompleta. Em adição a isso, a adversidade presente nesse parágrafo é completada por uma relação do tipo condicional, mediada por conjunção se, tornando evidente no discurso que o relacionamento Deus-fiel baseado apenas na crença individual é imperfeito, sendo necessária a "ação concreta" (pagamento do dízimo) para que este se plenifique.

Também podemos encontrar na preleção de Macedo várias figuras que remetem ao materialismo. A pregação apega-se a aspectos menostranscendentais ou reflexivos, privilegiando aspectos práticos e materiais. Isso ocorre quando Macedo trata do Paraíso, já que se atém especialmente a elementos concretos (as riquezas) e ao poder exercido pelo homem naquele ambiente (segundo Macedo, ele estaria somente abaixo de Deus). É comum encontrar termos como administrador, domínio e outros ligados ao ato de dominar e possuir.

Em uma leitura geral do texto, podemos verificar que o discurso do bispo Macedo contém uma série de excertos da Bíblia entrecortados e costurados no restante da fala. É diferente como ocorre, por exemplo, na liturgia católica, na qual excertos completos são lidos e depois explicados e interpretados pelo sacerdote. O jogo intertextual criado nessa fala é justamente o de recorrer aos textos bíblicos para endossar seus argumentos.

É perceptível a descontinuidade dos trechos utilizados, visto que Macedo nem sempre recorre ao mesmo texto em sua preleção e, mesmo que o fizesse, isso não obedeceria a uma sequência. Os excertos escolhidos passam a impressão de encaixar-se perfeitamente à fala do bispo, mesmo que tenham sido extraídos de livros relativamente díspares (como Deuteronômio, do Antigo Testamento, e Tiago, do Novo).

Assim, por meio de uma "recontextualização" do texto bíblico à sua fala, em que discursos distintos, ainda que de proveniências distintas, servem a uma prática religiosa em particular (FAUSTO NETO, 2002b), o bispo consegue transmitir uma sensação de credibilidade ao fiel, que adere ao discurso sem aparente questionamento - transforma-se em um argumento de autoridade, fundamentado na "palavra de Deus". 


\section{Considerações finais}

Ao longo da análise apresentada, pudemos constatar que o discurso de Macedo fundamenta-se em uma lógica bastante simples - que é impossível se chegar a Deus através de uma fé introspectiva, mas é preciso pô-la em prática mediante o pagamento do dízimo, sob pena de Deus não agir na vida do indivíduo e este permanecer sujeito à desgraça.

Contudo, a pregação é fortalecida, além das estruturas sintáticas e lexicais destacadas na seção anterior, por meio de uma estratégia enunciativa em que o bispo, ao utilizar o "eu" como se fosse o próprio Deus, reveste-se da figura divina, agindo como seu representante e assumindo sua autoridade. Ao proferir determinados trechos da Bíblia entremeados em seu discurso, sacerdote e divindade se confundem, dando a entender que ambos são uma única figura, a qual orienta os fiéis sobre seus desígnios. O mesmo ocorre no uso do "você", ao mesmo tempo generalizante e individualizado, em que o pastor, investido da autoridade divina, exorta os seguidores a seguir suas orientações.

Assim, as operações enunciativas utilizadas por Macedo, somadas à utilização planejada dos trechos bíblicos - entremeando-os junto à sua fala -, são estratégias fundamentais que conferem legitimidade e autoridade ao seu discurso, viabilizando sua pregação e ajudando-o a atingir seus objetivos na manutenção e conquista de seguidores.

No entanto, tais estratégias de enunciação revelam uma prática autoritária na relação entre interlocutores. Se, ao relembrarmos Benveniste (1989), o sujeito da enunciação (eu) somente existe em relação ao outro (tu), e a presença de ambos é imprescindível para haver a própria enunciação, esse tu é sufocado por um eu soberano, ambivalente (sacerdote-divindade), que a todo o momento dita a lógica do discurso e interpela seus ouvintes a agir conforme seu desejo. Aos fiéis, privados de voz nessa relação, resta o papel de ouvintes.

Essa "subjugação" do tu na relação enunciativa, em conjunto às diversas estruturas discursivas detectadas na pregação (expressões 
categóricas, orações subordinativas de causalidade e condicionantes, orações adversativas, entre outras), cria um cenário envolvente do qual o devoto não terá escapatória, a não ser seguir as orientações da instituição, se quiser encontrar-se com Deus e melhorar sua condição de vida - mesmo que, para isso, tenha de se pagar um preço (dízimo).

Enfim, o discurso aqui analisado coaduna-se com os intentos da IURD na relação que pretende criar com seus seguidores, mediante a qual a instituição se oferece como a única a trazer cura e libertação a quem a ela recorre ou, como diz Fausto Neto (2002a , p.155), se coloca como uma "'comunidade terapêutica' empreendedora de projetos de cura e de salvação mediante 'contratos simbólicos' que conferem a pastores - enquanto peritos - a condição mediadora e reguladora dos processos postos em prática".

Diante disso, retomamos o que Fausto Neto disse outrora sobre o papel das instituições religiosas como "atendedoras de demandas", em que elas se oferecem como remediadoras dos males imediatos dos indivíduos, procurando estabelecer com eles um elo similar ao de um vendedor com seus clientes. Essa relação adquire mais força pela própria situação televisiva, tratada por Brito (1999, p.11), já que a televisão é entendida como um instrumento de autopromoção e autovenda, tendo como meta principal estimular o consumo de seus espectadores.

Não se pode desconsiderar, afinal, que a televisão está, desde o seu surgimento, intrinsecamente ligada ao mercado e à 'lógica' do consumo. A própria programação da televisão é tratada como um produto que, como tal, também precisa ser promovido e vendido. Por isso, a programação da TV preocupa-se, antes de mais nada, com sua auto-promoção, com sua auto-venda. $O$ gesto interpelativo, por ser inerente à venda, passa a ser assim determinante no formato da programação televisiva.

Nesse cenário de religiosidade midiatizada, em que as pessoas não buscam apenas respostas para suas inquietações existenciais ou um norteador para suas vidas, mas uma resolução a seus problemas o mais imediatamente possível especialmente aqueles ligados a razões financeiras, de saúde ou emocionais -, 
as instituições remodelam suas táticas de persuasão para angariar o máximo de seguidores, ampliando assim seus raios de ação e, por conseguinte, seu poder.

Assim, quem dispuser de um aparato simbólico-discursivo mais eficaz e tiver maior competência para lidar com os meios de comunicação de massa (como a IURD o faz com maestria) adquire uma vantagem substancial em relação às "concorrentes". Logo, a lógica de mercado, mais do que nunca, tem se mostrado evidente - e, sobretudo, agressiva - nesse cenário religioso contemporâneo. 


\section{Referências}

ANTONIAZZI, A. et al. Nem anjos nem demônios: interpretações sociológicas do pentecostalismo. Petrópolis: Vozes, 1994.

ASSMANN, H. A igreja eletrônica e seu impacto na América Latina. Petrópolis: Vozes/ WACC-ALC, 1986.

BENVENISTE, E. Problemas de linguística geral II. Campinas: Pontes, 1989.

"Bispo Edir Macedo é indiciado por lavagem de dinheiro". Portal G1, Rio de Janeiro, 11/08/2009. Disponível em: http://jornalnacional.globo.com/Telejornais/ JN/0, MUL1263480-10406,00-BISPO+EDIR+MACEDO+E+INDICIADO+POR+LAVAGEM +DE+DINHEIRO.html. Acesso em: 20/03/2010.

BRITO, Y. C. F. "Cinema, televisão e vídeo: uma proposta de abordagem semiótica da recepção", 1999. Disponível em: http://www.eca.usp.br/associa/alaic/ Congreso1999/5gt/Yvana\%20Carla\%20.rtf. Acesso em: 26/03/2010.

FAIRCLOUGH, N. "A Análise Crítica do Discurso e a mercantilização do discurso: as universidades". In: MAGALHÃES, C. (Org.). Reflexões sobre a análise crítica do discurso. Belo Horizonte: FALE/UFMG, 2001a.

Discurso e mudança social. Brasília: Ed. da UnB, 2001b.

FAUSTO NETO, A. "Processos midiáticos e construção de religiosidades - dimensões discursivas". Revista Galáxia, São Paulo, v. 2, n. 3, p. 151-164, 2002a.

. "A religião teleterapeutizante: discursividades dos templos midiáticos". Revista Fronteiras - estudos midiáticos, São Leopoldo, v. 6, n. 2, p. 25-46, jul./dez. 2002b.

MACEDO, E. Como fazer a obra de Deus. Rio de Janeiro: Gráfica Universal, 1999. O poder sobrenatural da fé. 6a. ed. Rio de Janeiro: Gráfica Universal, 2002.

SODRÉ, M. "A salvação cotada em dólar". Observatório da Imprensa, Rio de Janeiro, 11/07/2001. Disponível em: http://observatoriodaimprensa.com.br/artigosd/ jd110720011p.htm. Acesso em: 21/03/2010. 
1 Trabalho apresentado no XIV Colóquio Internacional da Escola Latino-Americana de Comunicação (Celacom), realizado entre 17 e 19 de maio de 2010 no Memorial da América Latina, São Paulo-SP. Disponível em http://www2.metodista.br//unesco/1_Celacom\%202010/trabalhos.htm.

2 Jornalista, licenciado em Letras, mestrando em Comunicação pela Unesp de Bauru. Assistente de Suporte Acadêmico do Departamento de Psicologia da Unesp de Bauru. Email: bgarrido@fc.unesp.br. 